\title{
Morphology and Physico-Chemical Properties of Lowland Area of Yamuna River Bank, Mahewa Village of Prayagraj
}

\author{
S. Dogo ", Narendra Swaroop, P. Smitri Rao and T. Thomas
}

Department of Soil Science and Agricultural Chemistry, Sam Higgin Bottom University of Agriculture, Technology and Sciences, Allahabad, India

*Corresponding author

\section{Keywords \\ Soil morphology, Physical properties, Chemical properties, Soil profile, Soil horizons \\ Article Info \\ Accepted: 07 April 2019 Available Online: 10 May 2019}

\section{A B S T R A C T}

The study evaluated the morphology and physico- chemical, and characteristics as well as the nutrient status of two degraded lowland soils located in Yamuna river bank of Mahewa village area of Prayagraj. Profile depth of $1 \mathrm{~m}$, with $20 \mathrm{~cm}$ interval for 5 different samples are examined for their morphology, physical and chemical properties. Total numbers of 5 samples were collected from different depth at $20 \mathrm{~cm}$ interval through a profile. All field laboratory analyses were done following standard procedures. Results indicate that, the nutrient status of the lowland soils in the area were moderate. The nutrient status recorded a $\mathrm{pH}$ of 7.53 ,with $0.4 \mathrm{dSm}^{-1}$ electrical conductivity, the available nitrogen were moderate with $174.82 \mathrm{kgha}^{-1}$, organic carbon is high with $1.9 \%$, the organic matter was also found to be high with $3 \%$. The soil shows no carbonate threat with a record of $0.55 \%$. The physical properties of the soil show a bulk density of $1.32 \mathrm{Mgm}^{-1}$, and the porosity was $54.2 \%$, with a textural class of sandy clay loam of $72.4 \%$ sand, $25.2 \%$ clay, $2.4 \%$ silt, and a blocky to sub angular block structure, the morphology of the soil show a light brown to dark brownish color and the horizon boundaries show smooth to clearly smooth distinction, with a slightly abrupt distinction the soil show a consistency with friable at the surface, moderate to hard at the subsurface horizons.

\section{Introduction}

Soil morphology is the field observable attributes of the soil within the various soil horizons and the description of the kind and arrangement of the horizons (Buol et al., 2003). C.F. Marbut works on the reliance on soil morphology instead of the theories of pedogenesis which enables the classification of soil, because theories of soil genesis are both important and dynamic Soil Survey Staff (1993).
The observable attributes ordinarily described in the field include the composition, form, soil structure and organization of the soil, color of the base soil and features such as mottling, distribution of roots and pores, evidence of translocate materials such as carbonates, iron, manganese, carbon and clay, and the consistence of the soil.

The observations are typically performed on a soil profile. A profile is a vertical cut, twodimensional, in the soil and bounds one side 
of a pedon. The pedon is the smallest threedimensional unit, but not less than 1 meter square on top that captures the lateral range of variability. Soil morphology can also be used to help make tillage decisions. In some coarse-textured soils where the E horizons are compact and form a tillage pan, the root system is restricted and yields may be low in the dry season because of plant water stress (Vepraskas et al., 1987). Crop yields can be increased in these soils by sub soiling to rip or fracture the pan, but such tillage should only extend to the top of the $\mathrm{B}$ horizon to avoid eventually deepening the compacted layer (Trouse, 1983). Parent material, organism, relief and time are soil forming factors that influence the morphological, physical, chemical and biological characteristics of soil (Myansa, 2001). Understanding of soil genesis, morphology and other key of soil properties is a requirement for sustainable use of soil resources.

Soil texture is one of the features that exhibit the greatest uniformity especially within short distances apart. Russell (1973) commended that once form, Soil texture remains relatively static over a period of time. Most soils exhibits variation in soil texture at the topsoil layers with an increasing fineness with depth (Amalu, 1998). Structure, consistence, etc. of the soil are highly variable morphological attributes influenced by the soils mineral composition. Webster and Wilson (1980) observed that iron-rich parent materials such as basalt and dolerite will weathered to give a soil with high iron content and good structure, while granites which are low in iron but high in quartz will weathered into weak structured soil. Soil structure and texture influence its consistence. The productive capacity of any soil depends on its morphological characteristics and properties such as structure, texture, consistence etc, which influence the fertility status of soils. The study was conducted to examine the morphology, physical and chemical properties of the soil in a soil profile of lowland Yamuna river bank of Mahewa village, east of Pragrayaj India.

\section{Materials and Methods}

The study was conducted to study the morphological physical and chemical attributes in soil profile of lowland soil of Mehewa village area of Prayagraj. The field experiment was carried out during the Kharif season 2018-2019 in the lowland area of Mahewa village of Prayagraj Uttar pradesh. The lowland is located in the Yamuna river bank of Mahewa village of Pragrayaj Uttarpradesh, at latitude $25^{\circ} 24^{\prime} \mathrm{N}$ and longitude $81^{\circ} 51^{\prime} \mathrm{E}$, with height of $14 \mathrm{~m}$ above sea level

\section{Climatic condition of the study area}

Agro climatically, Pragraya district represents the subtropical belt of the south east of Uttar Pradesh, and is endowed with extremely hot summer and fairly cold winter. The maximum temperature of the location ranges between $46^{\circ} \mathrm{C}$ and seldom falls below $4^{\circ} \mathrm{C}-5^{\circ} \mathrm{C}$. The relative humidity ranges between $20-94 \%$. The average rainfalls of this area are around $1100 \mathrm{~mm}$ annually. Pragrayaj has three seasons: a hot, dry summer, a cool, dry winter and a hot, humid monsoon, the Summer lasts from March to September with daily highs reaching up to $48{ }^{\circ} \mathrm{C}$ in the dry summer (from March to May) and up to $40{ }^{\circ} \mathrm{C}$ in the hot and extremely humid monsoon season (from June to September). Begins in June, and lasts till August; high humidity levels prevail well into September. Winter runs from December to February, with temperatures rarely dropping to the freezing point. The daily average maximum temperature is about $22^{\circ} \mathrm{C}\left(72{ }^{\circ} \mathrm{F}\right)$ and the minimum about $9{ }^{\circ} \mathrm{C} \quad\left(48^{\circ} \mathrm{F}\right)$ Pragrayaj never receives snow, but, experiences dense winter fog due to numerous 
wood fires, coal fires, and open burning of rubbish-resulting in substantial traffic and travel delays. Its highest recorded temperature is $48^{\circ} \mathrm{C}\left(118.4^{\circ} \mathrm{F}\right)$, and its lowest is $-2{ }^{\circ} \mathrm{C}$ $\left(28^{\circ} \mathrm{F}\right)$ (Allahabad climate report, 2012).

\section{Sample collections and sample analysis}

Soil sample will be taken from upland soil, at a depth of $100 \mathrm{~cm}(1.0 \mathrm{~m}$ depth) from the profile site. A total of 5 samples will be collected at depth of $0-20 \mathrm{~cm}, 20-40 \mathrm{~cm}, 40-$ $60 \mathrm{~cm}, 60-80 \mathrm{~cm}$, and $80-100 \mathrm{~cm}$, from the profile and will be analyzed using both field and laboratory methods.

\section{Field method}

The field method will comprise the morphological properties such as color; structure, consistence, mottles, pores; concretions, horizon boundaries, effervescence and designation were assessed and described according to procedures outlined in the revised taxonomy guideline (Soil survey staff, 1999). The horizon boundaries will be examine using the survey staff methods (1999)

\section{Samples analysis}

Disturbed soil samples were air-dried, ground and passed through a $2 \mathrm{~mm}$ sieve to obtain the fine soil fractions for determination of physical and chemical soil properties. The particles size distribution (Texture) was determined by the Bouyoucos hydrometer method (Piper, 2002). Soil pH was determined in soil-water suspension using glass electrode $\mathrm{pH}$ meter (Jakcson, 1958) and the soil electrical conductivity was also be determined after $\mathrm{pH}$ (Wilcox, 1950). Organic carbon was determined by the dichromate wet oxidation method of Walkley and Black (Jackson, 1969). Bulk density and the particle density, total porosity well as the water retention capacity were determined using the graduated measuring cylinder of black (1965). The organic matter was determined by using a Vernmelen multiplication constant of 1.274, and the available nitrogen was determined by the Subbiah and Ashija (1956). And the carbonate was determined by Schollenberger (1945).

\section{Results and Discussion}

\section{Morphological characteristics of the pedons units}

Key morphological properties of the profile are shown in Table 1. The profile was well drained with friable moist consistency and moderately hard to hard when dry.

The profile depth of the study area varied from $0-100 \mathrm{~cm}$ from location respectively which according to Prassad and Srivastav (1993) explain that the variation in the soil depth is due topography of the area as well as the slope on which the soil is form. Hajara et al., (1990) also shows that profile depth is an important influence on crop which as a result of the deep solum which provides higher soil volume for nutrient and water retention.

The profile is deep (1m), with a weak fine subangular blocky to a few platy structure in horizon A, which according to Wernstedt and Spencer (1967) occur due the rich alluvial deposited of lime stone, clay and sand material, which occur during the marine sedimentation of various particles.

Soil color is produced by the types of minerals present and the organic matter content. The color were observed to be light yellowish brown (10YR6/4) when dry to a dark brown (10YR4/3) when moist as we move down the profile. Similar report by Nyle and Brady (2006) explain that brown soil color is due to the presence of high 
organic matter accumulation. This also in line with USDA (2014) that color development and distribution of color within a soil profile are part of weathering, similarly the color of the lowland as shown in Table 1, varied from yellowish brown (10YR6/4) when dry to dark brown (10YR4/4) when moist which according to Linn et al., (2000), with depth below the soil surface, colors usually become lighter, yellower, or redder due to activities of mineral found in the soil.

The Soil horizons were quite distinct ranging from abrupt to clear with smooth horizon boundaries. Soil pores were common and well distributed within the profile. The soils were also well developed with a weak argillic Bhorizon. Major pedon units of land form were use to describe the morphological characteristic of the soil, and are presented in Table 1.

\section{Soil physical properties}

\section{Soil particle size distribution}

Table 2 presents the data on particle size distributions of the study site. From among the soil properties most commonly measured during soil inventories, soil texture is the next most important variable after soil organic matter content that is thought to influence particle density (Ball et al., 2000). The soil texture was sandy clay loam in the upper and lower horizons of the soil unit, with an overall average texture of sandy clay loam $72.4 \%$ sand, $25.2 \%$ clay, $2.4 \%$ silt which goes line with the findings on the geographical and social profile study of Allahabad Shodhganga (2011) recorded that all Allahabad belongs to 4 class of soil and are predominantly sandy loam and clay. These coarse textures control the variability of nutrient storage capacity, limit the water holding capacity and roots may grow under sub-optimal soil water due to water deficits (Gacheneand Kimaru, 2003).
Similar founding were recorded by Krishivigyan Kendra (2015), that Allahabad soil were group into 4 class of which are mainly sandy loam and clay and $48 \%$ of the class are sandy clay loam soil.

The sand content decreased gradually with depth as the proportion of finer particles increased, partially due to illuviation and argillation in the Bthorizons Nyle $\mathrm{C}$ and Brady (2008). Soil texture is the most stable physical characteristic of the soils which has influence on a number of other soil properties including structure, soil moisture availability, erodibility, root penetration and soil fertility Msanya et al., (2003). This is because texture is a composite of the coarse fraction (sand) and the finer fractions (silt and clay) and an increase or decrease in one component imparts the opposite effect on the other and hence affects physico-chemical properties of the soils (Phiri et al., 2014). Clay for example has been reported to interact with organic matter and increase water and nutrient holding capacity (Landon, 1999).

Wakindiki and Ben-Hur (2000) expressed that in soils containing more than $20 \%$ clay, the clay particles act as a cementing agent and will increase aggregate stability against raindrops and decrease surface sealing. The silt/clay ratio, an indicator of soil susceptibility to detachment and transport, was less than the threshold of 0.4 implying moderate resistances to erosion (Wanjogu, 1992).

\section{Particle density and bulk density}

The result on the particle density and bulk density were presented in table 2 respectively. Lower value of $1.66 \mathrm{gcm}^{-3}$ on the surface horizon and to a maximum of $3.3 \mathrm{gcm}^{-3}$ on the $B_{1}$ horizon and $3.0 \mathrm{gcm}^{-3}$ on the $\mathrm{B}_{3}$ horizon of the lower pedon unit with a mean value of $2.40 \mathrm{gcm}^{-3}$ is shown in the Table. And this 
particle density of soil varies with the nature or type of textural class (Rhulman et al., 2006). It is also evident that the particle density of different mineral particle-size fractions can be distinguished statistically. When working with soil inventory data sets originating from large geographic areas, the predictive capability of any regression equation developed is likely to be influenced by the soil taxonomic range (Heuscher et al., 2005). While the bulk density showed a mean value bulk density of $1.32 \mathrm{gcm}^{-3}$ with a maximum value of $1.43 \mathrm{gcm}^{-3}$ and $1.45 \mathrm{gcm}^{-3}$ in $\mathrm{Bt} 2$ and $\mathrm{B}_{3}$ with lower bulk density of $1.25 \mathrm{gcm}^{-3}$ in horizon $\mathrm{Ap}$ and $\mathrm{A}$, which according to Melich (1984) bulk density of the soil is influence by the amount of organic matter present in a soil. Similarly, Okalebo et $a l .$, (2012) indicated that relative bulk density value in a top soil reduce water infiltration there by favored surface run-off whereas increase in same depth may lead to poor root growth decrease aeration and decrease water infiltration.

Similar result was obtained by Ebenezer et $a l$. , (2004) where he shows that bulk density of lowland give a higher value which is presumably due to low organic matter. The bulk densities of the various soil profiles in the benchmark watersheds were very high. These data fall within the range of bulk densities for cultivated and non-cultivated soils and the formation of pans in African soils, as described (Brady and Weill, 1999).

\section{Water retention capacity and porosity}

Porosity is an index of the relative pore volume in the soil. Jahn et al., (2006) suggested that it is the total amount of pore space or that portion of soil volume not occupied by solid particles, but occupied by air and water. The result for the pore space of the soil pedons from Table 2 ranges from $42 \%-75 \%$ in the lowland, and with a minimum value of $42 \%$ in horizon $\mathrm{B}_{1}$ and a higher value of $75 \%$ horizon $\mathrm{Ap}$, to an average mean value of $54.2 \%$ respectively. This shows that the surface horizon recorded a higher value of the pore space, it also show that the porosity follow an irregular trend in the soil horizon. Porosity result is related to the trend in bulk density values, soil disturbance, the farm operation and increased organic matter decomposition explain the decreased or increased in porosity of the horizons. Also, this indicated that porosity is a good indicator of physical degradation of soil (Asio et al., 2015). The result on the percentage water holding capacity of the pedon units were shown in Table 2, the results from lowland having a minimum value of $433.7 \%$ in the Ap horizon and a higher value of $56.25 \%$ in the $\mathrm{B}_{3}$ horizon, with an average mean value of $50 \%$ in the whole horizons. Which according to Dasog and Patil (2011), indicated that variation in the water holding capacity of the soil in the horizon may be due to a factor of variation in clay and organic matter content of the soil pedon.

\section{Some chemical properties of the study area}

\section{Soil reaction $(\mathrm{pH})$ and $\mathrm{EC}$}

The result on the soil $\mathrm{pH}$ as shown from the lowland data in table 3 revealed that the soil is in lowland are neutral to slightly alkaline in reaction. The $\mathrm{pH}$ increase with increase in soil depth with a lower of 7.40 in horizon Ap, and a higher value of 7.68 and 7.64 in $B_{1}$ and $B_{2}$, with an average mean value of 7.58 in the lowland horizon. Which according to Canfield (1981) found that $\mathrm{pH}$ of 6.5-7.5 in the lowland water shed area may be due to other anthropogenic activities that occur in the area as well as increase in the lake size volume ratio and other minerals contents. Hand and Paulic (1991) report a similar result of PH 7.3 in lowland lake area of Florida which according to them may be due to 
change in nutrient variability. Electrical conductivity is the measure of salinity, in which too much of concentration in soil interfered with performance of plants and the root function in terms of nutrient uptakes (Hodges, 2007) from Table 3, the soil from the lowland study area showed a an electrical conductivity value range of $0.494 \mathrm{dSm}^{-1}$, $0.497 \mathrm{dSm}^{-1}$, and $0.422 \mathrm{dSm}^{-1}$ in Ap, A and $\mathrm{B}_{2}$ horizons with a lower value of $0.381 \mathrm{dSm}^{-1}$ in the $B_{1}$ horizons, and higher value of 0.596 $\mathrm{dSm}^{-1}$ was recorded in the $\mathrm{B}_{3}$ horizon. The mean value of the electrical conductivity in the lowland is $0.47 \mathrm{dSm}^{-1}$. This soil EC provide estimation within field soil difference associated with the top soil thickness there by serve as root zone suitability for crop growth and yield in lowland (kitchen et al., 1999).

Organic carbon, organic matter, and available nitrogen

The soil organic carbon is known to exert beneficial influence on the soil structure, porosity, permeability and aeration (Sehgal, 1996). The percentage organic carbon content of the soil from lowland area as shown in (Table 3 ) ranges from a lower value of $0.9 \%$ in horizon Ap to a higher value of $1.35 \%$ in horizon $\mathrm{B}_{3}$, with a mean average value of $1.11 \%$ the whole horizons. The percentage organic matter value ranges from $1.55 \%$ in
Ap horizon to a higher value of $2.21 \%$ and $2.33 \%$ in the $A$ and $B_{3}$ horizons with the $B_{3}$ giving the higher value, the average mean value of the percentage organic matter in the lowland is $1.91 \%$. The fraction of finer soil particles of a given soil type represents an important predictor of organic carbon content (Parton et al., 1987). Organic carbon content is influenced by various regional factors, such as soil type, texture, topography, land use type, and management practices (Haoand Kravchenko, 2007). Similar report was recorded by Sehgal (1996). The available nitrogen status of the lowland study area as shown in Table 3 ranges from $314 \mathrm{kgha}^{-1}$ to $408 \mathrm{kgha}^{-1}$, with a lower value of $267 \mathrm{kgha}^{-1}$ in horizon $\mathrm{A}$ and a higher value of $408 \mathrm{kgha}^{-1}$ in horizon $B_{1}$, with a mean average value of $351 \mathrm{kgha}^{-1}$. The available nitrogen in the lowland is moderately higher which according Jaiswal (2006), recorded available nitrogen range of $250 \mathrm{kgha}^{-1}$ to $500 \mathrm{kgha}^{-1}$ are considered moderate for in soil. This also agreed with Brady (2008) that correlation between organic carbon and nitrogen determine the availability of nitrogen in the soil. The maintenance of nitrogen level in the soil is a function of the maintenance of carbon and organic matter in the soil is dependent to no small degree on the level of nitrogen in the soil (Das, 1996).

\section{Morphological features of lowland area of Mahewa village}

\begin{tabular}{|l|l|}
\hline Attributes & Descriptions \\
\hline Location angles (latitude longitude) & $25^{0} 25^{\prime} 5^{\prime} \mathrm{N}, 81^{0} 50^{\prime} 58^{\prime \prime} \mathrm{E}$ \\
Mean annual temperature & $26.1^{\circ} \mathrm{C}\left(79.0^{\circ} \mathrm{F}\right)$ \\
Mean annual rainfall & $981 \mathrm{~mm}$ \\
Locations & Yamuna river bank \\
Elevation above sea level & $14.0 \mathrm{~m}$ \\
Soil slope & Mid slope \\
Vegetation types & Shrubs, trees, lown grasses \\
Superficial deposits & Alluvial \\
Land use management & grazing \\
Grid ref & lowland \\
& \\
\hline
\end{tabular}


Table.1 Morphological characteristics of lowland area

\begin{tabular}{|c|c|c|c|c|c|c|c|}
\hline Horizon & $\begin{array}{l}\text { Depth } \\
\text { cm }\end{array}$ & Texture & $\begin{array}{l}\text { Color matrix } \\
\text { Dry wet }\end{array}$ & Structure & $\begin{array}{l}\text { Consistency } \\
\text { Moist dry }\end{array}$ & $\begin{array}{l}\text { Horizon } \\
\text { boundary }\end{array}$ & $\begin{array}{l}\text { Carbonate } \\
\text { reaction }\end{array}$ \\
\hline Ap & $0-20$ & SCL & 1yb10YR6/4 yb10YR3/3 & $\mathrm{Gr}$ & md & as & st \\
\hline $\mathbf{A}$ & $20-40$ & SCL & lyb10YR6/4 db10YR3/4 & Sbk & md & as & st \\
\hline $\mathbf{B}_{1}$ & $40-60$ & SCL & Lyb10YR6/4 db10YR3/4 & Sbk & hd & cs & ev \\
\hline $\mathbf{B}_{2}$ & $60-80$ & SCL & lyb10YR6/4 db10YR4/3 & $\mathrm{Pl}$ & Vf & cs & ev \\
\hline $\mathbf{B}_{3}$ & $80-100$ & SCL & db10YR4/3 & $\mathrm{Pl}$ & hd & cs & sl \\
\hline
\end{tabular}

Key:

$\mathrm{SCL}=$ sandy clay loam, lyb =light yellow brown, $\mathrm{db}=$ dark brown, lb=light brown, gr $=$ granular, hd $=$ hard, $\mathrm{fr}=$ friable, very friable, $\mathrm{sbk}=$ sub angular blocky, $\mathrm{pl}=$ platy, fi $=$ firm, $\mathrm{db}=, \mathrm{sh}=$ slightly hard, hd=hard, $\mathrm{md}=$ moderately hard, cs=clearly smooth, ve= violently effervescence=strongly effervescence. Sl =slightly effervescence

Table.2 Physical properties of the lowland area

\begin{tabular}{|c|c|c|c|c|c|c|c|c|c|c|}
\hline \multirow{2}{*}{$\begin{array}{c}\text { Horizon } \\
\text { Ap }\end{array}$} & \multirow{2}{*}{\begin{tabular}{|c|} 
Depth \\
cm
\end{tabular}} & \multicolumn{3}{|c|}{$\begin{array}{l}\text { Texture\% } \\
\text { sand silt clay }\end{array}$} & \multirow{2}{*}{$\begin{array}{c}\begin{array}{c}\text { Texture } \\
\text { class }\end{array} \\
\text { SCL }\end{array}$} & \multirow{2}{*}{$\begin{array}{c}\begin{array}{c}\text { PD } \\
\mathbf{M g c m}^{-3}\end{array} \\
1.66\end{array}$} & \multirow{2}{*}{$\begin{array}{c}\begin{array}{c}\text { BD } \\
\mathbf{M g c m}^{-3}\end{array} \\
1.25\end{array}$} & \multirow{2}{*}{$\begin{array}{c}\begin{array}{c}\text { Pore space } \\
(\%)\end{array} \\
75\end{array}$} & \multirow{2}{*}{$\begin{array}{c}\begin{array}{c}\text { Solid phase } \\
(\boldsymbol{\%})\end{array} \\
25.0\end{array}$} & \multirow{2}{*}{$\begin{array}{c}\begin{array}{c}\text { WHC } \\
(\%)\end{array} \\
43.75\end{array}$} \\
\hline & & 68 & 2 & 30 & & & & & & \\
\hline $\mathbf{A}$ & $20-40$ & 75 & 3 & 22 & SCL & 2.00 & 1.25 & 62 & 37.5 & 53.13 \\
\hline $\mathbf{B}_{1}$ & $40-60$ & 68 & 10 & 22 & SCL & 3.33 & 1.42 & 42 & 57.0 & 50.00 \\
\hline $\mathbf{B}_{2}$ & $60-80$ & 67 & 8 & 25 & SCL & 2.50 & 1.25 & 50 & 50.0 & 46.87 \\
\hline $\mathbf{B}_{3}$ & $\begin{array}{l}80- \\
100\end{array}$ & 60 & 8 & 32 & SCL & 3.00 & 1.43 & 42 & 58.0 & 56.25 \\
\hline Total & 5.0 & 67.6 & 6.2 & 26.2 & SCL & 2.40 & 1.32 & 54.2 & 45.5 & 50.00 \\
\hline
\end{tabular}

Table.3 Profile description of the lowland area

\begin{tabular}{|c|c|l|}
\hline Horizon & Depth (cm) & Profile characteristics \\
\hline AP & $0-20$ & $\begin{array}{l}\text { Dark brown (10yr4/3), sandy clay loam, granular structure to weak subangular } \\
\text { blocky, friable to moderately hard consistency, pH 7.4,little abrupt to clearly } \\
\text { smooth boundary }\end{array}$ \\
\hline $\mathbf{A}$ & $20-40$ & $\begin{array}{l}\text { Dark brown (10YR4/3) sandy clay loam, subangualr blocky structure, } \\
\text { moderately hard consistency, pH 7.5 clearly smooth boundary }\end{array}$ \\
\hline $\mathbf{B}_{\mathbf{1}}$ & $40-60$ & $\begin{array}{l}\text { Dark brown (10YR4/3) sandy clay loam, subangular blocky structure, } \\
\text { moderately hard consistency, pH 7.6, clearly smooth boundary. }\end{array}$ \\
\hline $\mathbf{B}_{\mathbf{2}}$ & $60-80$ & $\begin{array}{l}\text { Dark brown(10YR4/3) sandy clay loam, platy structure, hard consistency,pH7.6, } \\
\text { clearly smooth boundary }\end{array}$ \\
\hline $\mathbf{B}_{\mathbf{3}}$ & $80-100$ & $\begin{array}{l}\text { Dark brown(10YR4/3) sandy clay loam, platy structure hard consistency, pH 7.6 } \\
\text { clear smooth boundary }\end{array}$ \\
\hline
\end{tabular}


Table.4 Chemical properties of the lowland area

\begin{tabular}{|l|l|l|l|l|l|l|l|}
\hline Horizon & $\begin{array}{l}\text { Depth } \\
\mathbf{c m}\end{array}$ & $\begin{array}{l}\mathbf{p H} \\
\mathbf{1 : 2}\end{array}$ & $\mathbf{O C} \mathbf{( \% )}$ & $\begin{array}{l}\mathbf{O M} \\
\mathbf{( \% )}\end{array}$ & $\begin{array}{l}\mathbf{N} \\
(\mathbf{k g h a}\end{array}$ & $\begin{array}{c}\mathbf{E C}_{\mathbf{2 5}} \\
\left(\mathbf{d S m}^{-\mathbf{1})}\right.\end{array}$ & $\begin{array}{l}\text { Carbonate } \\
(\mathbf{\%})\end{array}$ \\
\hline $\mathbf{A p}$ & $0-20$ & 7.40 & 0.90 & 1.55 & 157.0 & 0.49 & 0.45 \\
\hline $\mathbf{A}$ & $20-40$ & 7.55 & 1.28 & 2.21 & 110.0 & 0.49 & 0.78 \\
\hline $\mathbf{B}_{\mathbf{1}}$ & $40-60$ & 7.68 & 0.95 & 1.64 & 251.4 & 0.38 & 0.55 \\
\hline $\mathbf{B}_{\mathbf{2}}$ & $60-80$ & 7.64 & 1.05 & 1.81 & 235.7 & 0.42 & 0.50 \\
\hline $\mathbf{B}_{\mathbf{3}}$ & $80-100$ & 7.62 & 1.35 & 2.33 & 220.0 & 0.59 & 0.45 \\
\hline Mean & 5.00 & 7.58 & 1.11 & 1.91 & 174.82 & 0.47 & 0.55 \\
\hline
\end{tabular}

\section{Percentage carbonate}

Carbonate affects both the physical condition and nutrient availability in soil. A high concentration of carbonate for example lime forms a hard layer pan (calcic and petrocalcic horizons) (Sehgal, 1996).

The result on the carbonate content from the study areas as showed from the lowland area in Table 4 indicated a lower values $0.45 \%$ of carbonate in horizon $\mathrm{Ap}$ and $\mathrm{B}_{3}$, with a higher value of $0.78 \%$ in horizon $A$, and a mean total average value of $0.55 \%$ in the was recorded in the lowland. This value range has no limitation to crop production which according to Sehgal (1996) fall in the very suitable class of soil suitability classification.

In conclusion, the study of lowland area of Mahewa village of pragrayaj show the $\mathrm{pH}$ to be slightly alkaline, the soil of the locations show no salinity problem and the organic carbon and organic matter content of the location were moderately high, the available nitrogen status show a moderate values.

The physical properties of the soil such good bulk density as well as the particle density were good for the soil rating, the soil also show a good water retention capacity in the lowland. And the percentage pore spaces recorded were normal

\section{References}

Allahabad climate. Climate Maps India. Archived from the original on 12 July 2012. Retrieved 3 october 2018. http://www.allahabad.climatetemps. com

Amalu, U.C., 1998. Evaluation of properties of selected soils of Cross River Area and their management for increase cassava yield. Global Journal of Pure and Applied Sciences, 4 (3): 243-249.

Brady, NC., Weil RR. 2008. The nature and properties of soils. 13th Edn. Pearson Education, Inc.; 965.

Ball, B.C., D.J. Campbell, and E.A. Hunter. 2000. Soil compatibility in relation to physical and organic properties at 156 sites in UK. Soil Tillage Res. 57:83-91. doi: 10.1016/S0167-1987(00)00 145-8.

Brady, CN., and Weil RR 1999. The nature and properties of soils, 12th Ed., 881 pp., Macmillan Publishing Co., New York

Buol, Stanley W., Southard, Randal J., Graham, Robert C., McDaniel, Paul A. (2003). Soil Genesis and Classification, 5th Edition. Ames, Iowa: Iowa State Press, A Blackwell Pub. Co. Pp. 494.

Canfield, D.E., Jr.1981.Chemical and trophic state characteristics of Florida lakes in relation to regional geology. 
University of Florida, Gainesville.a. $444 p$.

Das, D.K., (2015). Introductory Soil Science. Kalyani publisher New Delhi Indian, Pp. 542.

Ebenezer Annan-Afful, Noriko Iwashima, Ernest Otoo, Kwame Osafredu Asubonteng, Daisuke Kubota, Akira Kamidohzono, Tsugiyuki Masunaga and Toshiyuki Wakatsuki (2004). Nutrient and bulk density characteristics of soil profiles in six land use systems along toposequences in inland valley watersheds of Ashanti region, Ghana, Soil Science and Plant Nutrition,

Gachene, CKK, Kimaru, G., 2003. (Eds.) Soil fertility and Land productivity: A guide for extension workers in the Eastern Africa Region. RELMA Technical handout Series 30. Nairobi, Kenya: Regional Land Management Unit (RELMA), Swedish International Development Cooperation Agency (SIDA).; Pp. 164.

Hodges, SC., 2007. Soil Fertility Basics. Soil Science Extension North Carolina State University, Available at http//.plantstress.com/Articles/min_def iciency_i/soil_fertility.pdf.

Jahn, R., H.P. Blume, V.B. Asio, and P. Schad. 2006. Guidelines for Soil Description (4 ed.). FAO, Rome.

Jaiswal, P.C., (2003).Soil, Plant and water analysis. New Delhi India

Jacson, ,M.L, (1967). Soil chemicals: prentise Hall(India) pvt. Ltd., New Delhi and Technology. 2010; 4(3): 217-225.

Krishivigyan, Gaina-acholipithoragh, disttpithoragh (Uttarakhadh) india265530:2015 soil test report: www.http://allabad.kvk4.in

Landon, JR., Booker 1991.Tropical Soil Manual. A handbook for soil survey and agricultural land evaluation in the tropics and subtropics. Longman
Scientific and Technical Publishers, Essex.; Pp. 474.

Mganga, KZ., Musimba NKR, Nyangito MM, Nyariki DM, Mwang'ombe AW. Improving hydrological properties of degraded soils in semi-arid Kenya. Journal of Environmental Science

Msanya, BM., Kaaya AK, Araki S, Otsuka H, Nyadzi G. I. Pedological characteristics, general fertility and classification of some benchmark soils of Morogoro District, Tanzania. African Journal of Science and Technology, Science and Engineering Series. 2003; 4(2): 101-112.

Phir,i AT., Msaky JJ, Mrema J, KanyamaPhiri, G Y, Msanya BM. 2014. Effects of pigeon pea - groundnut intercropping system on selected soil properties. International Journal of Plant and Soil Science.; 3(4): 397407.

Wakindiki, IC., Ben-Hur M.2002. Soil mineralogy and texture effects on crust ,micromorphology, infiltration and erosion. Soil Science Society of America Journal.; 66: 597-605.

Wanjogu, SN., 1992. The genesis, classification and erosion susceptibility of the soils of the semiarid Sirima and Mukogodo Catchments, Laikipia District, Kenya. MSc. Thesis, University of Nairobi.

Rühlmann, J., Korschens, M., Graefe, J.,2006. A new approach to calculating particle density considering propter of soil organic and mineral matrix. Geoderma, 130, 272-283.

Russell, E., Walter 1973.Soil condition and plant growth. $\left(10^{\text {th }} \mathrm{ed}\right)$. London: Longman. Pp. 67-70.

Schollenberger, C.J., 1945. Determination of carbonates in soil. Soil Sci.59:57-63.

Shegal, J.L., (1996) Pedology concepts and applications, third edition, Kalyani publisher New Delhi India. 
Shodhganga, 2011. Geographycal and social profile report of Allahabad. http://shodhganga.inflibnet.ac.in/ jspui stream/106031/18632/2/chapter $-2 p d f$

Soil Survey Staff, 2006. Keys to Soil Taxonomy. 10th Edn. United States Department of Agriculture and Natural Resources Conservation Service. Washington, Pp. 341.

Troues, 1983. Observation on under the row subsoiling after conventional tillage. Tillage Rev: 3:67-82

Vepraskas, M.J., G.S. Miner and G.F. Peedin. 1987. Relationships of rainfall and soil properties to effect sub soiling on tobacco yield. Agron. J. Pp. 3152-56.

Webster, C. C. and Wilson, P. N., 1980. Agriculture in the Tropics. English Language Book Society and Longman Group Limited, United Kingdom England.

\section{How to cite this article:}

Dogo, S., Narendra Swaroop, P. Smitri Rao and Thomas, T. 2019. Morphology and PhysicoChemical Properties of Lowland Area of Yamuna River Bank, Mahewa Village of Prayagraj. Int.J.Curr.Microbiol.App.Sci. 8(05): 452-461. doi: https://doi.org/10.20546/ijcmas.2019.805.053 